\title{
EDITORIAL
}

\section{Jacques Derrida: relances}

Em outubro de 2014, completaram-se 10 anos da morte de Jacques Derrida, um dos pensadores mais comprometidos com o exercício da filosofia, tanto em termos de pensamento quanto em termos institucionais, mas que, desde os anos 1960, vem deixando sua marca também em diversas outras áreas do conhecimento, em especial a dos estudos literários. Dificilmente se podem compreender as discussóes que têm caracterizado os debates em torno da literatura e da cultura nesse período sem a referência direta, frequentemente polêmica, ao nome de Derrida ou ao termo "desconstrução". Trata-se, hoje, de um lugar de debate reconhecido mesmo por aqueles que pretendem descrever as insuficiências e os pontos de saturação de nossa relação com a teoria e com a própria literatura.

O que a efeméride do passamento do autor deveria evocar, para além da homenagem pessoal ou do reconhecimento do significado histórico de seu trabalho, é a força com que sua obra continua se metamorfoseando, assumindo as mais diversas formas de exigência e de estímulo de pensamento. $\mathrm{O}$ presente número da revista Alea, ao olhar para tal paisagem com a rapidez característica de uma chamada de artigos, pretende também, nesse relance, recolocar em cena sua vibrante atualidade.

Se perdemos a figura calorosa da pessoa - cuja inteligência e abertura de espírito, bem pouco comuns, tornaram-se amplamente conhecidas - é porque passamos mais explicitamente, independentemente da experiência e da nomeação do luto, a uma época de escrita. $\mathrm{Na}$ ausência do autor, em torno do qual a obra tendia a se reagrupar e se desdobrar, em seus variados momentos de atuação e intervenção públicas, passamos a um estado de repetição e de deslocamento: de edição, de tradução, de arquivamento e de inventário, é certo, mas também de invenção de um novo modo de viver com Derrida no qual o "póstumo" - que faz parte de toda estrutura de sentido - aparece mais dramaticamente como parte integrante da questão.

Os artigos que associamos a esta iniciativa incidem sobre vários aspectos relacionados ao "legado" derridiano: os desafios da edição dos Seminários, o mapeamento da tradução e da leitura da obra de Derrida em outros espaços linguísticos (de língua inglesa e espanhola, por exemplo), a problematização da ideia da "morte" como conceito, a amizade como experiência da proximi- 
dade e da distância comparável à experiência da tradução, o poder espectral das palavras em movimento nesse pensamento, suas relaçóes com a psicanálise e a ficção, a singularidade da sua abordagem do "político", a articulação da sua reflexão sobre o "poder" com a noção de "soberania" estão entre as questôes mais instigantes associadas a esse legado.

A propósito de questóes bem diferentes associadas à escrita e à produção temática da obra de Derrida, este volume traz igualmente textos sobre questóes mais pontuais, que a princípio teriam relação indireta com o recorte temático. Apesar disso, ou por isso mesmo, não deixam de transformar-se, de modo ainda mais evidente, qualquer que seja a velocidade de sua passagem pela obra de Derrida, em indícios da efetividade e da atualidade do relance. É o caso do texto sobre o conceito de "animal-estar", colocado em relação com a leitura de poesia, e dos três artigos que trazem para o diálogo com os temas derridianos textos-chave da literatura brasileira, do modernismo ao contemporâneo. $\mathrm{O}$ interesse significativo despertado pelo tema trouxe aos editores uma experiência forte não apenas do nome Derrida, mas dos temas e dos gestos derridianos disseminados no cotidiano da pesquisa e do pensamento. Uma resenha de obra de Derrida traduzida recentemente no Brasil, sobre o tema da "visibilidade", fecha o volume.

Depois de décadas de debate público mundial, a importância e o impacto da obra de Derrida não precisam de confirmação. Ao contrário, expóem-se ao mapeamento e ao debate sobre seu sentido, ao mesmo tempo em que a própria configuração dessa obra vai sendo redesenhada pela publicação dos inéditos, um enorme corpus que corresponde a 40 anos de ensino e de intervençôes mais específicas. A experiência do relance confirma a percepção de que, se o legado derridiano tende a inserir em seu corpo uma particular experiência do endereçamento aos temas e à escrita do autor, ele não se reduz, entretanto, ao luto ou ao simples desdobramento imitativo. Se sua "lição" associa ao exercício da leitura pontual uma atenção exigente, ela também prescreve a consideração generosa do sentido do acontecimento ao qual igualmente nos expomos. 